\title{
Changes in microbial populations during co-composting of dewatered sewage sludge with pruning wastes in windrow piles
}

\author{
AMIR HOSSEIN NAFEZ ${ }^{1}$, MAHNAZ NIKAEEN ${ }^{1, \vartheta}$, AKBAR HASSANZADEH ${ }^{2}$, SAFOORA KADKHODAEI ${ }^{1}$ \\ ${ }^{1}$ Department of Environmental Health Engineering, School of Health, Isfahan University of Medical Sciences. Hezar Jerib Avenue, Isfahan, Iran \\ Tel.: +98-31-37923278, Fax.: +98-31-36682509, ^email: nikaeen@ hlth.mui.ac.ir \\ ${ }^{2}$ Department of Statistics and Epidemiology, School of Health, Isfahan University of Medical Sciences. Hezar Jerib Avenue, Isfahan, Iran
}

Manuscript received: 21 July 2020. Revision accepted: 18 September 2020.

\begin{abstract}
Nafez AH, Nikaeen M, Hassanzadeh A, Kadkhodaei S. 2020. Changes in microbial populations during co-composting of dewatered sewage sludge with pruning wastes in windrow piles. Biodiversitas 21: 4655-4662. The aim of this paper was to study the composting of sewage sludge (SS) and pruning waste as bulking agent with regard to abiotic factors and succession of functional microbial groups. To prepare the composting piles bulking agent and SS in volumetric ratios of 1:1 (TW1), 2:1(TW2), and 3:1(TW3) were used, and a pile of raw sludge was used as control. Samples for investigation were obtained from the composting piles at time intervals of 5-7 d. The temperature of the control pile and TW1 was just $37^{\circ} \mathrm{C}$ and did not reach the thermophilic phase. The number of thermophilic bacteria increased to $14 \log \mathrm{CFU} \mathrm{gDW}{ }^{-1}$ in the thermophilic phase. The salmonella was lost on the $47^{\text {th }}$ and $19^{\text {th }}$ days of the composting process, for TW2 and TW3, respectively. There was a significant correlation between mesophilic fungi with mesophilic bacteria $(\mathrm{r}=0.942, \mathrm{P}<0.001)$. The majority of the microbial populations inspected revealed their maximum numbers towards the end of the thermophilic phase, with decreasing tendencies afterward. The number of evaluated microorganisms was controlled by differences in physicochemical parameters at different composting phases. The results revealed that the scheduling of the thermophilic period, as well as the microbial community and environmental situations, affects the microbial structure andTW2 had the best quality compared to other piles in achieving the best thermophilic phase and elimination of pathogenic microorganisms.
\end{abstract}

Keywords: Bulking agent, compost, sewage sludge, thermophilic, windrow

\section{INTRODUCTION}

Sewage sludge (SS) is a valuable resource as a fertilizer because of its high organic matter $(\mathrm{OM})$ and nutrient content. However, raw SS is inappropriate for direct land application because of unstable OM, pathogens, weed seeds, and the problems related to preservation and transportation (Hao et al. 2019). Composting is an effective process for treatment of SS prior to land application, in which pathogens and weed seeds are destroyed and the heterogeneous OM are converted to more stable substances by the activity of different microbial groups (Villar et al. 2016a). Because of high moisture and low $\mathrm{C} / \mathrm{N}$ ratio of SS it should be mixed with different bulking agents that provide sufficient porosity and absorb the additional moisture in the sludge composting matrix. If the bulking agent ratio is properly adjusted all organic wastes can be composted in a satisfactory manner and the compost obtained from SS presents a high level of maturity (Wang et al. 2018; Yuan et al. 2016).

There are numerous methods for SS composting. Zazouli and Ala reported that increasing the volumetric ratio of the bulking agent to SS, in an aerated static pile composting process, improved the temperature rising rate and shortened the composting period (Zazouli and Ala 2019). The effectiveness of the composting process is directly associated with the structure of microbial communities in turned windrows and aerated static piles, which can be influenced by temperature, $\mathrm{pH}$, moisture content, and C: $\mathrm{N}$ ratio (Nafez et al. 2015a). In fact, composting relies upon the activity of microorganisms because of their key roles in OM degradation. Therefore, characterizing and quantifying the microbial populations could reveal the performance of the composting process, the rate of $\mathrm{OM}$ degradation, and the quality of product (Nafez et al. 2015b). Gómez-Silván et al. (2020) by evaluating microbial communities in a full-scale SS composting pile concluded that microbial communities could be used as an alternative for composting efficiency (Gómez-Silván et al. 2020). Wang et al. (2018) studied the factors of microbial community in SS composting with inorganic bulking agent in a cylindrical reactor and showed that microbial succession was interrelated with oxidationreduction potential (Wang et al. 2018).

Indicator and pathogenic bacteria have also received particular attention in the process of composting. The composting process, if not properly managed, might sustain proliferation and dispersion of potentially pathogenic bacteria. Consequently, microorganisms have only recently been identified as good indicators of the stability and maturity of compost. Microbial succession of composting particularly depends on the temperature of the pile, which represents the various phases of composting (GómezSilván et al. 2020; Liu et al. 2018). Time-temperature approach is the most important criteria that have commonly been applied for the assessment of the microbial quality of compost. However, various studies in the literature have shown that despite meeting the appropriate time- 
temperature conditions, some pathogens are able to survive in the compost (Thomas et al. 2020; Lu et al. 2020).

Microbiological analysis could provide a suitable tool for biosafety assessment in compost. Furthermore, in order to minimize risks from land application, certain biological criteria must be met in SS-derived compost. Although a large number of studies focused on microbial communities in different composting processes, there are a few studies on SS composting. Moreover, the differences in bacterial and fungal succession and their relationships with physicchemical aspects have not been comprehensively considered. The aim of the present study was to investigate the changes in microbial population as well as the survival of pathogenic and indicator bacteria during SS composting with different proportions of pruning waste as the bulking agent. The effect of some physicochemical parameters and operational conditions on changes of microbial parameters was also determined.

\section{MATERIALS AND METHODS}

\section{Composting process}

In order to determine the microbial population during the composting, digested SS (obtained from the SS dewatering room in the South Isfahan Wastewater Treatment Plant (WWTP) (Isfahan, Iran)) was mixed with green plant wastes (a mixture of grass clippings, tree leaves and small twigs from WWTP area ) at 3 proportions (1: 1=turned windrow1 (TW1), 1: 2=TW2 and 1: 3=TW3 (v: v)) and then compost ingredients were piled and composting proceeded for 12 weeks by windrow system. A pile containing SS without any addition was also used as a control (TW0). The amount of moisture content, OM content, $\mathrm{pH}$, and $\mathrm{C} / \mathrm{N}$ ratio of digested $\mathrm{SS}$ used in this study was approximately $77.8 \pm 3.1 \%, 52.8 \pm 3.9 \%, 7.6 \pm 0.4$, and $11.7 \pm 0.6$, respectively. The approximate dimensions of the piles were as follows: base: $2.5 \mathrm{~m}$; height: $1.25 \mathrm{~m}$; length: 3-4 $\mathrm{m}$ and they were trapezoidal in shape. Composting experiments were carried out at the uncovered composting platform and the humidity of the piles was control throughout the trial. Mechanical turning was used for aeration of windrow piles and the piles were turned every 7-10 d with a front-end loader during the composting process. Samples were collected weekly (every 5-7 d) for analyzing physicochemical and microbial parameters. Each sample was a mixture of three subsamples taken from different points along each pile. Samples were then placed in sterile bags and instantly transported to the laboratory for analyzing the physicochemical and microbial factors.

\section{Physicochemical analysis}

The temperature was measured at 3 points of the middle of each pile from different directions by a bar thermometer at the time of sampling and the average was reported as the sample temperature. The Moisture content was determined by drying the samples for $24 \mathrm{~h}$ at $70 \pm 5^{\circ} \mathrm{C}$ to consistent weight using a laboratory electrical oven (Thompson et al. 2001). The OM content was measured by determining the loss-on ignition at $550^{\circ} \mathrm{C}$ for $2 \mathrm{~h}$ in a muffle furnace and according to the OM content, the percent of organic carbon (C) was determined. Nitrogen content was measured as described by the US Department of Agriculture and US Composting Council (2001) (Thompson et al. 2001), and its concentration determined by DR5000 Spectrophotometer (Hach Co., USA). Consequently, $\mathrm{C} / \mathrm{N}$ ratio was computed based on the concentration of total $\mathrm{C}$ and N. Analysis of $\mathrm{pH}$ was performed at compost/distilled water ratio of 1:10 (w/v) using portable $\mathrm{pH}$ probe (Eutech pH1500, Singapore).

\section{Microbiological analysis}

Initial suspensions for microbiological analyses were prepared by the addition of $20 \mathrm{~g}$ of compost to $180 \mathrm{ml}$ of sterile saline solution $(1: 10 \mathrm{w} / \mathrm{v})$. Then samples were diluted with sterile saline solution and a10-fold dilution series was used for analyses. In order to monitor the composting process, total and fecal coliforms, Clostridium perfringens, and fecal streptococcus as indicator bacteria and Salmonella spp. as pathogenic bacteria were analyzed using the multiple-tube fermentation technique according to the standard methods (Thompson et al. 2001; APHA 2018). Concentration of cultivable mesophilic and thermophilic bacteria, mesophilic and thermophilic fungi, and Actinomycetes were also estimated using the dilutionplating method (APHA 2018; Farhadkhani et al. 2018; Nafez et al. 2015b; Thompson et al. 2001).

Different media were used for the enumeration of microbial groups as follows: lactose broth and brilliant green broth incubated at $37^{\circ} \mathrm{C}$ for $24-48 \mathrm{~h}$ for total coliforms and EC broth incubated at $44^{\circ} \mathrm{C}$ for $24-48 \mathrm{~h}$ for fecal coliforms. Furthermore, dextrose broth and Pfizer Selective Enterococcus (PSE) agar were incubated at $35^{\circ} \mathrm{C}$ for 24-48 $\mathrm{h}$ for fecal streptococcus in the probable and confirmatory tests, respectively. For Clostridium perfringens enumeration, liquid Thioglycolate and Tryptose Sulphite Cycloserine (TSC) agar, were incubated at $35^{\circ} \mathrm{C}$ for $24-48 \mathrm{~h}$ in anaerobic conditions (9-13\% carbon dioxide); moreover, Gram staining, motility, and nitrate reduction tests were performed on suspected colonies (Watkins et al. 2015).

Selenite-F, XLD agar, triple sugar iron (TSI) agar, and urea agar incubated at $37^{\circ} \mathrm{C}$ for $24-48 \mathrm{~h}$ were used for Salmonella spp. detection. To estimate the number of bacteria, fungi, and Actinomycetes, the relevant dilutions of samples were spread-plated in duplicate on the following media; Sabourad dextrose agar (supplied with $250 \mathrm{mg} / \mathrm{L}$ Chloramphenicol) was incubated at $25^{\circ} \mathrm{C}$ for $3-5 \mathrm{~d}$ and $45^{\circ} \mathrm{C}$ for 5-7 $\mathrm{d}$ for mesophilic and thermophilic fungi, respectively; Starch casein agar (supplied with $100 \mathrm{mg} / \mathrm{L}$ Nistatin) was incubated at $45^{\circ} \mathrm{C}$ for $5-7 \mathrm{~d}$ for Actinomycetes and Tryptic soy agar (TSA) medium (supplied with $100 \mathrm{mg} / \mathrm{L}$ Nistatin) was used for growth of mesophilic and thermophilic bacteria incubated for 24-48 h at $37^{\circ} \mathrm{C}$ and $45^{\circ} \mathrm{C}$, respectively. All microbiological media were obtained from Merck (Darmstadt, Germany).

\section{Data analysis}

The microbial counts were changed to $\log _{10} \mathrm{CFU} / \mathrm{g}$ DW and $\log _{10} \mathrm{MPN} / \mathrm{g}$ DW for statistical analysis. ANOVA 
analysis and Pearson correlation tests were performed with the SPSS program version 20.0 on physicochemical and microbial data achieved in the samples at different composting phases. Normality and homogeneity of the variances were checked using the Levene test, before ANOVA. The level of statistical significance was assumed at $\mathrm{P}<0.05$.

\section{RESULTS AND DISCUSSION}

\section{Composting process and abiotic factors}

The variation of physicochemical parameters is illustrated in Figure 1. This study revealed that more bulking agent ratios in the compost pile led to an earlier achievement of the thermophilic phase and the longer duration of this phase. Koolivand et al. reported that an appropriate mixing ratio could maintain and support the microbial community to present a high degradation rate of petroleum hydrocarbons (Koolivand et al. 2017). Generally, there were significant differences for almost all factors among compost from different piles, even for those coming from the same mixtures $(p<0.05)$. Temperature is one of the most significant factors for assessment of composting processes, because it affects the sanitation capability and microbial activity of the process (Salgado et al. 2019). As a result of high moisture content and anaerobic conditions, the maximum temperature in TW0 and TW1 was just $37^{\circ} \mathrm{C}$; consequently, these piles did not reach the thermophilic phase and their data were not shown. Moreover, the thermophilic phase in TW2 was longer than the other piles. The temperature of the piles rapidly increased and thermophilic temperatures of TW2 $\left(60-65^{\circ} \mathrm{C}\right)$ and $\mathrm{TW} 3\left(55-60^{\circ} \mathrm{C}\right)$ piles remained for 14 and $24 \mathrm{~d}$, respectively. These high temperatures in the thermophilic phase, which were preserved for some days to ensure that OM would become more stable and pathogenic microorganisms were inactivated (Bazrafshan et al. 2016).

The highest moisture content was observed in TW0 (78\%) followed by TW1 (63\%) (Data not shown). According to previous studies in the literature, one reason for the creation of anaerobic conditions in compost piles is high initial moisture content (Ma et al. 2020; Liu et al. 2018). According to (Nafez et al. 2015a), due to the high moisture content of SS, it must be mixed with dry materials that absorb the moisture and provide sufficient porosity for composting of SS. The high moisture content in composting mixtures not only prevents the formation of thermophilic phase, but also creates satisfactory conditions for survival of pathogens due to the exposure to sublethal temperatures (Villar et al. 2016b; Kadkhodaei et al. 2016). On the other hand, the moisture content of initial mixtures in TW2 and TW3 was in a range of 55-65\%, which seems appropriate for composting (fig1). The moisture content of the piles decreased from $55.2-63.5 \%$ to $20.7-26.3 \%$ during composting process because of the high temperature and mechanical aeration.
The $\mathrm{pH}$ values in the early stages of the process were 7.7 and 7.5 for TW2 and TW3 piles, respectively. Degradation of OM and accumulation of organic acids can decline $\mathrm{pH}$ at the beginning of the process (Zazouli and Ala 2019). Generally, the values of $\mathrm{pH}$ for both piles after the $2^{\text {nd }}$ week gradually increased to a rate of 8.5 in the $5^{\text {th }}$ week. The $\mathrm{pH}$ values of all products are within the range (6.0-8.5) suggested as suitable for land application. Abtahi et al. also stated that the maximum metabolic activity and bacterial growth occurred in a suitable $\mathrm{pH}$ range of 6-8 (Abtahi et al. 2020).

In our study, similar to the previous studies (Zazouli and Ala 2019; Heydari and Miraki 2016), with the degradation of $\mathrm{OM}$, the $\mathrm{C} / \mathrm{N}$ ratio declined continuously from 28-41 to the lowest level of 8.5-12 at the end of the process. As shown in fig 1 the OM content decreased significantly from $70 \%$ and $77.5 \%$ to $25 \%$ and $30 \%$ in TW2 and TW3, respectively. According to Koolivand et al, the addition of organic amendments supports microbial diversity and accelerates the succession of microbial populations (Koolivand et al. 2019). As the OM became more stable, the microbial activity, temperature, and $\mathrm{OM}$ degradation rate gradually decreased, revealing the end of the thermophilic phase.
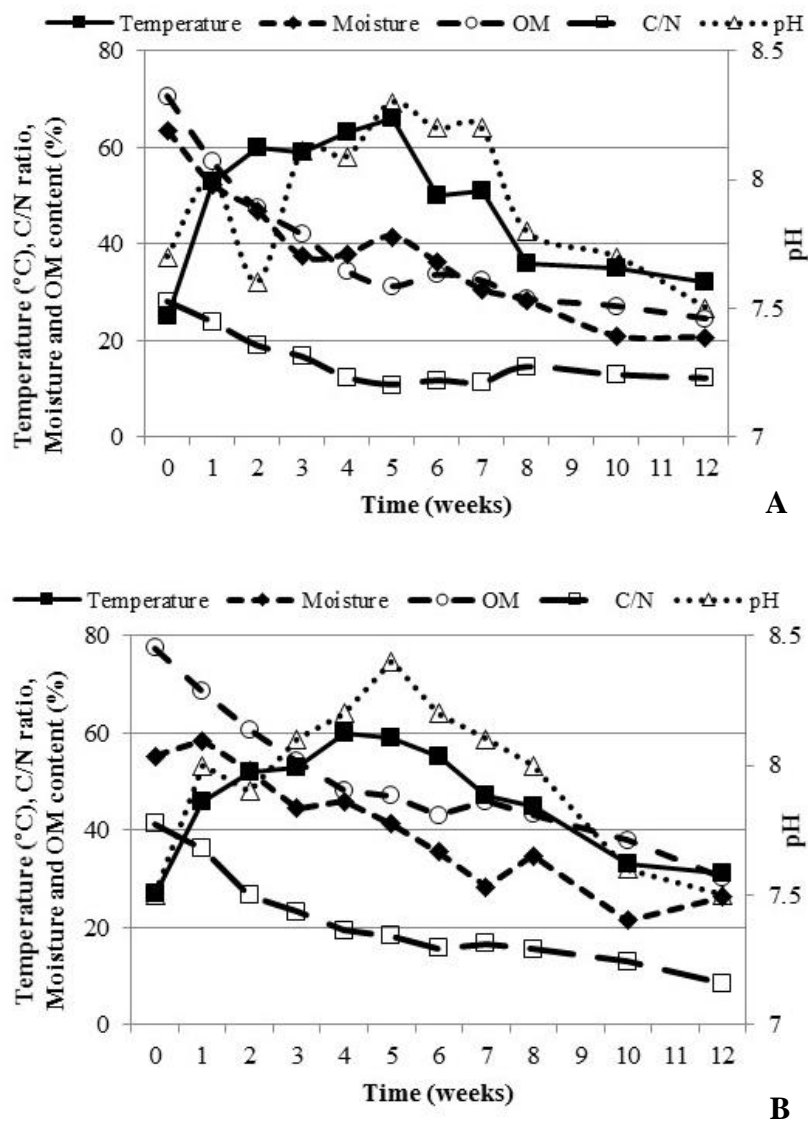

Figure 1. Variation of physicochemical parameters in TW2 (A) and TW3 (B) 
Table 1. Evolution of indicator and pathogenic bacteria $(n=3)$

\begin{tabular}{|c|c|c|c|c|c|c|}
\hline $\begin{array}{l}\text { Time } \\
\text { (d) }\end{array}$ & Pile & $\begin{array}{l}\text { Total coliform } \\
(\log \text { MPN gDW'-1) }\end{array}$ & $\begin{array}{l}\text { Fecal coliform }(\log \\
\left.\text { MPN } \text { gDW }^{-1}\right)\end{array}$ & $\begin{array}{l}\text { Fecal streptococci } \\
\left(\log \text { MPN gDW-1) }^{-1}\right)\end{array}$ & $\begin{array}{l}\text { Salmonella } \\
(\text { MPN 4gDW-1) }\end{array}$ & 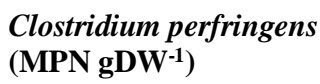 \\
\hline \multirow{2}{*}{1} & TW2 & $8.6^{\mathrm{a} *}(4.2)^{* *}$ & $7.6^{\mathrm{a}}(3.6)$ & $4.8^{\mathrm{a}}(1.9)$ & $12.7^{\mathrm{a}}(8.8)$ & $405000^{\mathrm{a}}(25000)$ \\
\hline & TW3 & $8.6^{\mathrm{a}}(4.3)$ & $7.6^{\mathrm{a}}(2.6)$ & $4.8^{\mathrm{a}}(2.7)$ & $307000^{\mathrm{b}}(15000)$ & $10000^{b}(1300)$ \\
\hline \multirow{2}{*}{13} & TW2 & $7.9^{\mathrm{a}}(3.5)$ & $7.6^{\mathrm{a}}(3.3)$ & $7.1^{\mathrm{b}}(3.3)$ & $9.6^{\mathrm{a}}(7.0)$ & ND \\
\hline & TW3 & $8.0^{\mathrm{a}}(3.6)$ & $7.6^{\mathrm{a}}(3.9)$ & $7.9^{\mathrm{b}}(3.6)$ & $4.4^{\mathrm{a}}(2.7)$ & $1.1^{\mathrm{c}}(1.0)$ \\
\hline \multirow{2}{*}{19} & TW2 & $7.4^{\mathrm{ab}}(3.9)$ & $7.4^{\mathrm{a}}(3.0)$ & $5.3^{\mathrm{a}}(2.1)$ & $3.2^{\mathrm{a}}(2.1)$ & $0.9^{\mathrm{c}}(1.5)$ \\
\hline & TW3 & $6.9^{\mathrm{b}}(3.3)$ & $6.9^{\mathrm{ab}}(2.5)$ & $4.7^{\mathrm{a}}(2.0)$ & ND & $2.6^{\mathrm{c}}(3.3)$ \\
\hline \multirow{2}{*}{26} & TW2 & $6.6^{\mathrm{bc}}(3.0)$ & $6.0^{\mathrm{b}}(2.5)$ & $5.8^{\mathrm{ab}}(3.2)$ & ND & $1.9^{\mathrm{c}}(1.3)$ \\
\hline & TW3 & $6.5^{\mathrm{bc}}(3.4)$ & $6.0^{\mathrm{b}}(2.5)$ & $4.9^{\mathrm{a}}(2.1)$ & ND & $0.8^{c}(1.1)$ \\
\hline \multirow{2}{*}{41} & TW2 & $5.7^{\mathrm{c}}(2.5)$ & $5.6^{\mathrm{bc}}(2.1)$ & $6.3^{\mathrm{ab}}(3.7)$ & $12.7^{\mathrm{a}}(6.5)$ & ND \\
\hline & TW3 & $5.3^{\mathrm{cd}}(2.2)$ & $5.3^{c}(2.6)$ & $5.8^{\mathrm{ab}}(3.7)$ & ND & ND \\
\hline \multirow{2}{*}{47} & TW2 & $8.3^{\mathrm{a}}(3.2)$ & $8.3^{\mathrm{a}}(3.3)$ & $4.3^{c}(2.3)$ & ND & ND \\
\hline & TW3 & $6.6^{\mathrm{bc}}(2.3)$ & $6.6^{\mathrm{ab}}(2.8)$ & $4.1^{\mathrm{c}}(2.0)$ & ND & ND \\
\hline \multirow{2}{*}{54} & TW2 & $6.2^{\mathrm{c}}(3.1)$ & $4.8^{\mathrm{c}}(2.1)$ & $3.5^{\mathrm{c}}(2.2)$ & ND & ND \\
\hline & TW3 & $5.5^{\mathrm{c}}(2.5)$ & $3.5^{\mathrm{d}}(2.1)$ & $3.4^{\mathrm{c}}(2.3)$ & ND & ND \\
\hline \multirow{2}{*}{68} & TW2 & $4.4^{\mathrm{d}}(2.1)$ & $4.7^{\mathrm{c}}(2.4)$ & $2.5^{\mathrm{d}}(1.4)$ & ND & ND \\
\hline & TW3 & $4.9^{\mathrm{cd}}(2.8)$ & $3.4^{\mathrm{d}}(1.9)$ & $2.4^{\mathrm{d}}(1.2)$ & ND & ND \\
\hline \multirow{2}{*}{83} & TW2 & $1.6^{\mathrm{e}}(1.9)$ & $0.6^{\mathrm{e}}(1.0)$ & $2.4^{\mathrm{d}}(1.7)$ & ND & ND \\
\hline & TW3 & $\mathrm{ND}^{* * * *}$ & ND & $2.0^{\mathrm{d}}(1.5)$ & ND & ND \\
\hline
\end{tabular}

Note: * Different letters in each column indicate significant differences in the level of 0.05 (according to Duncan's test), **the values in parentheses are standard deviation, $* * *$ Not Detected

\section{Microbial parameters}

Composting is a biological process and its quality is directly associated to the succession of microbial populations (Ince et al. 2020). The results of microbiological parameters are shown in Table 1. Statistical analysis revealed significant differences in these microbial factors for the duration of the composting process. The composting process led to significant variations in microbial population constitution as demonstrated in Figure 2.

\section{Mesophilic and thermophilic bacteria}

Table 1 represents the changes of mesophilic and thermophilic bacteria. The number of mesophilic bacteria was approximately stable during the thermophilic phase but increased to some extent after the completion of this phase. This is similar to the results of (Ince et al. 2020) and (Villar et al. 2016a) who stated a decrease in bacteria during the thermophilic phase, followed by an increase when temperatures began to decrease. In the stabilization phase, the thermophilic and mesophilic bacteria decreased to a constant level, probably due to the sharp drop in moisture and OM content and lack of biodegradable compounds.

The microbial population during the thermophilic phase was controlled by bacteria as revealed by a higher microbial count in Figure 2. In the thermophilic phase, the temperature increased to $55-60{ }^{\circ} \mathrm{C}$, and accordingly, the number of thermophilic bacteria also increased to their maximum levels and reached $14 \log \mathrm{CFU} \mathrm{g} \mathrm{DW}{ }^{-1}$ (Table1). The number of mesophilic bacteria dropped after the beginning of process but (Tian et al. 2012) reported that all mesophilic microorganisms increased after the beginning of composting and then gradually decreased. Inconsistent results have been reported in the literature regarding the succession of microorganisms. Tian et al. reported that populations of all mesophilic microorganisms increased after the beginning of dairy manure and rice chaff composting and after that gradually decreased and next, when the temperature began to decrease the number of mesophilic microorganisms increased again (Tian et al. 2012). But in our study, the number of mesophilic bacteria dropped after the beginning of the composting process. Generally, during the composting process, the population of mesophilic bacteria was inversely related to the temperature, and had a direct correlation with moisture content. By reducing the moisture content of compost, all of the microbial parameters except mesophilic bacteria are decreased. It seems that the moisture reduction had no significant effect on mesophilic bacteria.

\section{Mesophilic and thermophilic fungi}

The number of mesophilic fungi was highest at the beginning of the composting process and dropped during the composting process, while the thermophilic fungi were just found in the late stage of the mesophilic phase and were not detected throughout the study. In contrast, mesophilic fungi displayed high sensitivity to temperature fluctuations and had a decreasing trend during the composting process. The fungal community was significantly higher than that in the previous literature, possibly because of organic bulking agent being used in this study. For example, in the study of Wang et al., by using the inorganic bulking agent, bacterial diversity significantly increased in the mesophilic phase and gradually decreased in the cooling phase, but fungal diversity consecutively decreased as the composting progress (Wang et al. 2018). 
Table 2. Correlation between physic-chemical and microbial parameters

\begin{tabular}{|c|c|c|c|c|c|c|c|c|}
\hline Parameter & Pile & Temperature & $\begin{array}{l}\text { Moisture } \\
\text { content }\end{array}$ & pH & $\begin{array}{l}\text { Total } \\
\text { coliform }\end{array}$ & $\begin{array}{l}\text { Fecal } \\
\text { coliform }\end{array}$ & $\begin{array}{l}\text { Fecal } \\
\text { streptococci }\end{array}$ & Salmonella \\
\hline \multirow[t]{2}{*}{ Moisture content } & Tw2 & 0.199 & & & & & & \\
\hline & Tw3 & 0.175 & & & & & & \\
\hline \multirow[t]{2}{*}{$\mathrm{pH}$} & Tw2 & $0.734 * *$ & $0.664 * *$ & & & & & \\
\hline & Tw3 & $0.846 * *$ & 0.336 & & & & & \\
\hline \multirow[t]{2}{*}{ Total coliform } & Tw2 & 0.291 & 0.413 & $0.510 *$ & & & & \\
\hline & Tw3 & $-0.552 *$ & $0.520^{*}$ & -0.216 & & & & \\
\hline \multirow[t]{2}{*}{ Fecal coliform } & Tw2 & -0.188 & 0.293 & 0.302 & $0.517 *$ & & & \\
\hline & Tw3 & -0.395 & 0.337 & 0.075 & $0.853 * *$ & & & \\
\hline \multirow[t]{2}{*}{ Fecal streptococci } & Tw2 & -0.062 & 0.300 & -0.166 & 0.062 & -0.013 & & \\
\hline & Tw3 & -0.057 & 0.302 & 0.033 & 0.013 & -0.048 & & \\
\hline \multirow[t]{2}{*}{ salmonella } & Tw2 & 0.328 & 0.376 & 0.266 & $0.636^{*}$ & -0.097 & $0.507 *$ & \\
\hline & Tw3 & -.0402 & 0.331 & 0.582 & 0.457 & -0.061 & -0.092 & \\
\hline \multirow[t]{2}{*}{ Clostridium perfringens } & Tw2 & -0.440 & 0.299 & -0.170 & 0.030 & -0.088 & -0.133 & -0.165 \\
\hline & Tw3 & $-0.578 *$ & 0.473 & -0.381 & $0.945^{* *}$ & $0.668 * *$ & -0.135 & $0.701 * *$ \\
\hline
\end{tabular}

Note: $*$ and $* *$ Correlation is significant at 0.05 and 0.01 level, respectively

As shown in Figure 2, a significant decrease in mesophilic fungi population was detected during the early thermophilic phase that is consistent with (Villar et al. 2016a; Wang et al. 2018). After the thermophilic phase, mesophilic fungi remained almost constant and finally, it increased due to temperature decline in the cooling phase. Moreover, the greatest impact of temperature on mesophilic fungi was observed in the final stages of composting that illustrates the importance of stabilization in inactivation of the fungal community. Inconsistent results have been stated in relation to the succession of fungal communities. (Jiang et al. 2017) accounted that most of the fungi were eradicated at temperatures above $50^{\circ} \mathrm{C}$ and recuperated below $45^{\circ} \mathrm{C}$, while (Ma et al. 2019) found high numbers of fungi during the thermophilic phase.

Mesophilic fungi with temperatures and $\mathrm{pH}$ value were inversely related, and with moisture, ambient temperature and $\mathrm{C} / \mathrm{N}$ had a direct relationship. Consequently, fungi grow better in the initial stages of composting (high $\mathrm{C} / \mathrm{N}$ and moisture content, low $\mathrm{pH}$, and temperature). The results underline an inhibitory effect of low moisture on the growth of mesophilic fungi. (Dastpak et al. 2017) reported that the $\mathrm{pH}$ value was acidic at the beginning and then the $\mathrm{pH}$ increased due to ammonification and consequently, the fungal growth is limited due to the $\mathrm{pH}$ rise.

There was a significant correlation between mesophilic fungi and mesophilic bacteria $(r=0.942, \mathrm{P}<0.001)$ which revealed that both of them have the same requirements. In the cooling phase, the thermophilic fungi were not detected and the number of mesophilic fungi slightly increased. In the study of (Ma et al. 2020), the number of all mesophilic microorganisms increased at the beginning of composting process due to easily available carbon and mesophilic conditions. The thermophilic and mesophilic fungi decreased in stabilization phase and reached a constant level due to the sharp drop in moisture and OM.

\section{Actinomycetes}

The Actinomycetes began to increase after the mesophilic phase and reached the highest number in active phase and the lowest number of Actinomycetes was also observed in cooling phase. Moreover, compared to total bacteria and fungi the growth of Actinomycetes was slower. According to (Varma et al. 2017), further growth of Actinomycetes in thermophilic phase is due to the making of favorable conditions for their growth. Pearson correlation showed that the temperature is effective on lowering all microbial communities, except Actinomycetes. As reported by (Liu et al. 2018; Ma et al. 2020), there is a direct correlation between moisture and the microbial community. Only Actinomycetes had an inverse correlation with the moisture content, which reveals that these microorganisms prefer the lower moisture content. On the other hand, the $\mathrm{pH}$ value has a direct effect on growth of Actinomycetes that could be one of the reasons for the increase of this group in final stages of composting (Figure 2).

\section{Indicator and pathogenic microorganisms}

One of the problems posed due to the direct use of SS in agriculture is the risk of plant and human contamination by pathogens. Large amounts of pathogenic microorganisms (e.g. bacteria, viruses, and protozoa) have initiated from the SS (Al-Gheethi et al. 2018). Table 2 indicates the effect of high temperature on the removal of pathogens. The results showed that the thermophilic phase caused a sharp decline in indicator microorganisms and pathogens which is probably due to the unfavorable condition for microorganisms during this phase. Kadkhodaei et al. (2016) reported that high temperatures decrease different microbial groups such as total and fecal coliforms. However, the type of applied waste for composting has a great effect on pathogens' existence. According to the report by Al-Gheethi et al. Salmonella spp., E. coli $\mathrm{O} 157: \mathrm{H7}$, and Shigella sp. are considered as main health concerns which could spread the disease to the human, while Enterobacter spp., Klebsiella spp., $C$. perfringens, S. aureus, and Streptococcus spp. are insignificant concerns which are considered opportunistic 
pathogenic microorganisms that cause disease in debilitated persons (Al-Gheethi et al. 2018).

At the beginning of composting, the number of total coliforms, fecal coliforms, and fecal streptococci were about $10^{9}, 10^{8}$, and $10^{5} \mathrm{MPN} / \mathrm{g} \mathrm{DW}$, respectively. A significant reduction was observed in the number of fecal coliforms in thermophilic phase. The microorganisms decreased to undetectable limits during the thermophilic phase. According to previous studies, the bulking agent affects environmental factors (e.g. porosity, $\mathrm{C} / \mathrm{N}$ ratio, or moisture content) and it can control the microbial community during the process (Nafez et al. 2015a; Wang et al. 2018). However, after the thermophilic phase, secondary growth of coliforms was observed in the piles.

As indicated in Table 1, in the early stages, the number of fecal streptococci increased to $7 \operatorname{logs} \mathrm{MPN} / \mathrm{g}$ DW and $7.9 \operatorname{logs} \mathrm{MPN} / \mathrm{g}$ DW in TW2 and TW3, respectively and after that, these bacteria decreased in both piles. (Zazouli 2019) and (Nafez et al. 2013) reported that the total coliforms have lower values in returned piles in the stability phase. Also in (Ma et al. 2019) study, the number of fecal coliforms and Streptococci in compost piles decreased from $\log 5$ and $\log 2.49$ to $\log 2.27$ and $\log 2.12$, respectively. Since the fecal streptococci are more resistant than fecal coliforms (Nafez et al. 2013), in the final compost fecal streptococci were traceable and can be used as a useful indicator for fecal contamination. Liu et al. (2018) reported that the use of fecal streptococci, as well as fecal coliforms and $C$.perfringens, could serve as an excellent method for detecting the existence of pathogens and identifying their origins related to the treatment and disposal of biosolids (Liu et al. 2018).

Table 2 shows the relationship between microbial parameters and temperature, moisture content, $\mathrm{C} / \mathrm{N}$, and $\mathrm{pH}$ in composting piles. Statistical analysis showed a significant relationship between total coliforms and $\mathrm{pH}$ for TW2. In TW3, total coliforms have a direct relationship with moisture content and have an inverse correlation with temperature. Although the correlation was just observed for total coliforms, concentration of all bacteria was affected by temperature and moisture content. (Bazrafshan et al. 2016; Kadkhodaei et al. 2016) reported that high temperatures in a composting pile reduced different microbial groups but the type of applied waste for composting has a great effect on pathogens.

As seen in Table 1, the fecal coliforms and salmonella decreased with increasing the temperature and finally reached an undetectable limit at the end of the process. According to the EPA guidelines, the number of fecal coliforms should be less than 1000 MPN / gDW consequently, both piles comply with the EPA's guidelines (Al-Gheethi et al. 2018; USEPA 2003).

As previously described, Salmonella was present at the initial stages, but was not found in the thermophilic phase. By increasing the temperature Salmonella decreased to undetectable limits in the final product. Our results revealed that salmonella was lost on the $47^{\text {th }}$ and $19^{\text {th }} \mathrm{d}$, for TW2 and TW3, respectively. In the study of (Ince et al. 2020), Salmonella completely disappeared in the first week. However, (Nafez et al. 2013) reported that Salmonella was not destroyed until the $21^{\text {st }}$ day of composting. According to (Nafez et al. 2013), temperature from 64 to $67^{\circ} \mathrm{C}$ for $2-3$ weeks is sufficient to inactivate Salmonella spp which is consistent with (Al-Gheethi et al. 2018) who reported that Salmonella spp. are resistant microorganisms that are readily acclimated to hostile environmental conditions. The statistical analysis showed an inverse correlation between $\mathrm{pH}$ and Salmonella. Salmonella grows well at a $\mathrm{pH}$ of 6.5-7.5 and doesn't grow at a $\mathrm{pH}$ value higher than 9.5 .
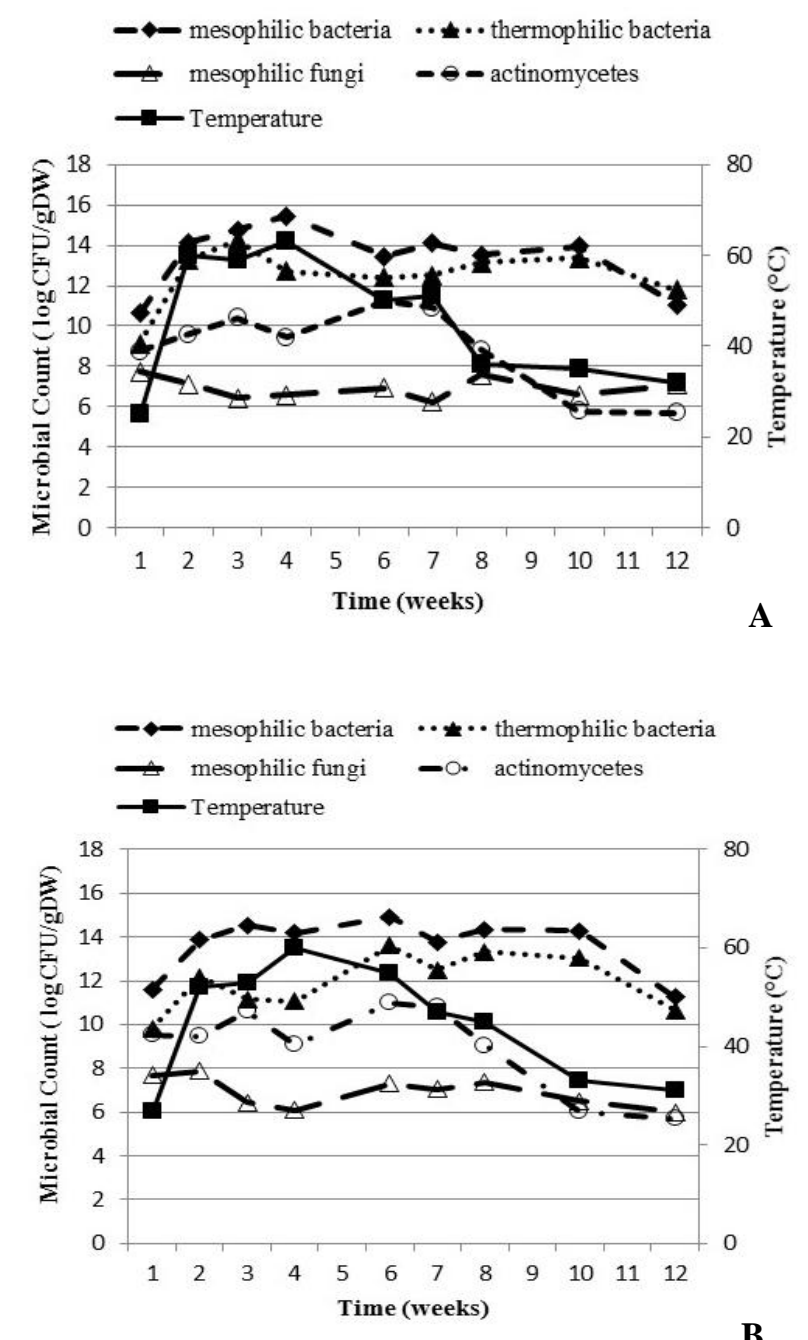

Figure 2. Trend of microbial population and temperature in TW2 (A) and TW3 (B) 
This study was also showed that Clostridium perfringens reached an undetectable limit in the 6th week (Table 1). The study of (Lasaridi et al. 2018) showed that Clostridium perfringens does not grow in the final product of sludge composting. However, the study of (GrantinaIevina and Rodze 2020) showed that the amount of this group of bacteria was high in the final product of anaerobic composting which may be due to the anaerobic conditions in this method. There was also an inverse correlation between the $\mathrm{pH}$ and some microbial parameters such as Clostridium perfringens (Table2). Vierheilig et al. (2013) stated that $C$.perfringens was not appropriate as an indicator of fecal pollution however they proposed that it could be used as a tracer for human sewage(Vierheilig et al. 2013).

The results of the physical, chemical, and microbial changes showed that TW2 had the best quality compared to the other piles in achieving the best thermophilic phase and elimination of pathogenic microorganisms. The number of fecal coliforms and Salmonella in the final compost of this pile reached to the undetectable limit. The results also indicated that compost product in TW3 pile was appropriate for land application from the microbial point of view. Consequently, the assessment of succession of microbial groups could be a suitable proxy in monitoring the stabilization state and pathogen removal in SS composting process.

\section{ACKNOWLEDGEMENTS}

This research was conducted with funding from the vice chancellery for research of Isfahan university of medical sciences (Research Project No. 392282).

\section{REFERENCES}

Abtahi H, Parhamfar M, Saeedi R, Villaseñor J, Sartaj M, Kumar V, Coulon F, Parhamfar M, Didehdar M, Koolivand A. 2020. Effect of competition between petroleum-degrading bacteria and indigenous compost microorganisms on the efficiency of petroleum sludge bioremediation: Field application of mineral-based culture in the composting process. J Environ Manag 258: 110013. DOI 10.1016/j.jenvman.2019.110013.

Al-Gheethi AA, Efaq, AN, Bala JD, Norli I, Abdel-Monem MO, Kadir M A. 2018. Removal of pathogenic bacteria from sewage-treated effluent and biosolids for agricultural purposes. Appl Water Sci 8: 74 DOI: $10.1007 / \mathrm{s} 13201-018-0698-6$.

American Public Health Association (APHA). 2005. Standard methods for the examination of water and wastewater. Washington, DC, USA.

Bazrafshan E, Zarei A, Mostafapour FK, Poormollae N, Mahmoodi S, Zazouli MA. 2016. Maturity and stability evaluation of composted municipal solid wastes. Health Scope 5 (1): e33202. DOI 10.17795/jhealthscope-33202.

Dastpak H, Farzadkia M, Joneidi A, Gholami M, Asgharnia H, Asadgol Z, Yeganeh Badi M. 2017. The efficiency of compost and vermicompos reactors for stabilizing organic waste and municipal sewage sludge. JBUMS. 19 (8): 50-57. DOI: http://jbums.org/article-1-6517-fa.html. [Persian]

Farhadkhani M, Nikaeen M, Yadegarfar G, Hatamzadeh M, Pourmohammadbagher H, Sahbaei, Z, Rahmani HR. 2018. Effects of irrigation with secondary treated wastewater on physicochemical and microbial properties of soil and produce safety in a semi-arid area. Water Res 144: 356-364. DOI: 10.1016/j.watres.2018.07.047.
Gómez-Silván C, Andersen GL, Calvo C, Aranda E. 2020. Assessment of bacterial and fungal communities in a full-scale thermophilic sewage sludge composting pile under a semipermeable cover. Bioresour Technol 298: 122550. DOI: 10.1016/j.biortech.2019.122550.

Grantina-Ievina L, Rodze I. 2020. Survival of pathogenic and antibioticresistant bacteria in vermicompost, sewage sludge, and other types of composts in temperate climate conditions. In: Meghvansi M, Varma A (eds.). Biology of Composts. Soil Biol 58. DOI: 10.1007/978-3030-39173-76.

Hao X, Chen Q, Van Loosdrecht MC, Li J, Jiang H. 2019. Sustainable disposal of excess sludge: Incineration without anaerobic digestion. Water Res 170: 115298. DOI: 10.1016/j.watres.2019.115298.

Heydari F, Miraki GH. 2016. Qualitative study of compost fertilizer produced in Zahedan Factory, considering physical and chemical characteristics. J Environ Sci Tech 18 (2): 336-341. [Persian]

Ince O, Ozbayram EG, Akyol Ç, Erdem E I, Gunel G, Ince B. 2020. Bacterial succession in the thermophilic phase of composting of anaerobic digestates. Waste Biomass Valor 11:841-849. DOI: 10.1007/s12649-018-0531-3.

Jiang C, Wu Y, Cheng Y. 2017. Bacterial and fungal communities and contribution of physicochemical factors during cattle farm waste composting. Microbiologyopen 6: e00518. DOI: 10.1002/mbo3.518.

Kadkhodaei S, Nikaeen M, Hatamzadeh M, Nafez AH, Hassanzadeh A. 2016. Monitoring of indicator and pathogenic bacteria during sewage sludge composting process. J Health Syst Res 12 (2): 160-165. [Persian]

Koolivand A, Abtahi H, Godini K, Saeedi R, Rajaei M S, Parhamfar M. 2019. Biodegradation of oil tank bottom sludge using a new twophase composting process: Kinetics and effect of different bulking agents. J Mater Cycles Waste Manag 21: 1280-1290. DOI: 10.1007/s10163-019-00881-x.

Koolivand A, Rajaei M S, Ghanadzadeh M J, Saeedi R, Abtahi H, Godini K. 2017. Bioremediation of storage tank bottom sludge by using a two-stage composting system: Effect of mixing ratio and nutrients addition. Bioresour Technol 235: 240-249. DOI: 10.1016/j.biortech.2017.03.100.

Lasaridi KE, Manios T, Stamatiadis S, Chroni C, Kyriacou A. 2018. The evaluation of hazards to man and the environment during the composting of sewage sludge. Sustainability 10 (8): 2618. DOI: 10.3390/su10082618.

Liu L, Wang S, Guo X, Zhao T, Zhang B. 2018. Succession and diversity of microorganisms and their association with physicochemical properties during green waste thermophilic composting. Waste Manag 73: 101-112. DOI: 10.1016/j.wasman.2017.12.026.

Lu W, Ye R, Ming Z, Pan C, Abbas Y, Stegmann R, Wang H. 2020. Performance evaluation in composting of sewage sludge with different bulking agents. J Environ Eng 146 (6): 05020002. DOI: 10.1061/(ASCE)EE.1943-7870.0001727.

Ma C, Hu B, Liu FY, Gao AH, Wei MB, Zhang HZ. 2020. Changes in the microbial succession during sewage sludge composting and its correlation with physicochemical properties. Nat Environ Pollut Technol 19 (1): 237-244.

Ma C, Hu B, Wei MB, Zhao JH, Zhang HZ. 2019. Influence of matured compost inoculation on sewage sludge composting: Enzyme activity, bacterial and fungal community succession. Bioresour Technol 294: 122165. DOI: 10.1016/j.biortech.2019.122165.

Nafez AH, Nikaeen M, Nabavi BF, Hatamzadeh M, Hassanzadeh A. 2013. Evaluation of composting process on removal of indicator and pathogenic bacteria in Isfahan composting factory. J Health Syst Res 9 (8): 837-850. [Persian]

Nafez AH, Nikaeen M, Bina B, Hassanzadeh A, Moghim S. 2015a. Evaluation of stability and maturity parameters in wastewater sludge composting with different aeration strategies and a mixture of green plant wastes as bulking agent. Fresen Environ Bull 24 (7): 2406-2414.

Nafez AH, Nikaeen M, Kadkhodaie S, Hatamzadeh M, Moghim S. 2015 b. Sewage sludge composting: quality assessment for agricultural application. Environ Monit Assess 187 (709): 1-9. DOI: 10.1007/s10661-015-4940-5.

Salgado MMM, Blu RO, Janssens M, Fincheira P. 2019. Grape pomace compost as a source of organic matter: Evolution of quality parameters to evaluate maturity and stability. J Cleaner Prod 216: 5663. DOI: $10.1016 /$ j.jclepro.2019.01.156.

Thomas C, Idler C, Ammon C, Amon T. 2020. Effects of the C/N ratio and moisture content on the survival of ESBL-producing Escherichia coli during chicken manure composting. Waste Manag 105: 110-118. DOI: $10.1016 /$ j.wasman.2020.01.031 
Thompson W, Leege P, Millner P, Watson M.2001). Test methods for the examination of composting and compost. The United States Composting Council Research and Education Foundation. The United States Department of Agriculture, Washington, DC.

Tian W, Li L, Liu F, Zhang Z, Yu G, Shen Q, Shen B. 2012. Assessment of the maturity and biological parameters of compost produced from dairy manure and rice chaff by excitation-emission matrix fluorescence spectroscopy. Bioresour Technol 110: 330-337. DOI: 10.1016/j.biortech.2012.01.067.

USEPA. 2003. Environmental regulations and technology: Control of pathogens and vector attraction in sewage sludge. Office of Research and Development, EPA, Washington, DC..

Varma VS, Das S, Sastri CV, Kalamdhad AS. 2017 Microbial degradation of lignocellulosic fractions during drum composting of mixed organic waste. Sustain Environ Res 27 (6): 265-272. DOI 10.1016/j.serj.2017.05.004

Vierheilig J, Frick C, Mayer R, Kirschner A, Reischer G, Derx J, Mach R, Sommer R, Farnleitner A. 2013. Clostridium perfringens is not suitable for the indication of fecal pollution from ruminant wildlife but is associated with excreta from nonherbivorous animals and human sewage. Appl Environ Microbiol 79: 5089-5092. DOI: 10.1128/AEM.01396-13.
Villar I, Alves D, Garrido J, Mato S. 2016a. Evolution of microbial dynamics during the maturation phase of the composting of different types of waste. Waste Manag 54: 83-92. DOI: 10.1016/j.wasman.2016.05.011.

Villar I, Alves D, Perez-Díaz D, Mato S. 2016b. Changes in microbial dynamics during vermicomposting of fresh and composted sewage sludge. Waste Manag 48: 409-417. DOI: 10.1016/j.wasman.2015.10.011.

Wang K, Mao H, Li X. 2018. Functional characteristics and influence factors of microbial community in sewage sludge composting with inorganic bulking agent. Bioresour Technol 249: 527-535. DOI: 10.1016/j.biortech.2017.10.034.

Watkins J, Sartory D, Analysts USCO. 2015. Evaluation of a membrane filtration method for the rapid enumeration of confirmed Clostridium perfringens from water. Lett Appl Microbiol 60: 367-371. DOI: 10.1111/lam.12383.

Yuan J, Chadwick D, Zhang D, Li G, Chen S, Luo W, Du L, He S, Peng S. 2016. Effects of aeration rate on maturity and gaseous emissions during sewage sludge composting. Waste Manag 56: 403-410. DOI: 10.1016/j.wasman.2016.07.017.

Zazouli M, Ala A. 2019. A review of co-composting municipal sewage sludge with a variety of biological waste. J Health 10 (1): 19-33. [Persian] 